\title{
Climate report 'subject to scientific cleansing'
}

London. A US lobby group partly financed by oil, power and automobile companies is trying to undermine the credibility of the latest report of the UN Intergovernmental Panel on Climate Change (IPCC) by accusing it of "scientific cleansing".

The accusation has been made by the Global Climate Coalition (GCC), an umbrella group of 60 industrial concerns, in a document that is currently being widely circulated in the Congress and elsewhere in Washington DC.

Its target is the latest five-yearly report of the IPCC, agreed in principle last November and published in London last week, which concludes in particular that the balance of scientific evidence "suggests a discernible human influence on global climate".

Such a conclusion is likely to boost demands for greater curbs on the use of fossil fuels. The coalition is now trying to throw doubt on its validity on procedural grounds, in particular by criticizing the decision of one of the report's authors to re-edit a chapter before final publication, after it had been peer-reviewed and approved.

But Ben Santer, the author concerned, an atmospheric scientist at the Lawrence Livermore National Laboratory in California, says the changes were endorsed by the IPCC and were necessary "to improve the report's scientific clarity". He describes the GCC's allegations as "dangerous and absurd".

The GCC last week issued a nine-page, line-by-line analysis of the changes made to Chapter eight of the report, dealing with the

\section{South African museums under review}

Cape Town. A draft white paper (policy document) on arts and culture released last week by Ben Ngubane, South Africa's Minister of Arts, Culture, Science and Technology, has done little to dispel uncertainty about the future of the country's natural history museums.

The report acknowledges that the national status of the 18 museums - which are currently funded by subsidies from the department, rather than by provincial or local authorities - needs to be reviewed. Five of them have major natural history collections, as do at least five provincial museums and one municipal one.

The latter, the Durban Museum of Natural Science, is the country's most popular museum. Its director, Brett Hendey, points out that if the review is intended to lead to an eventual across-the-board rationalization, it should include other institutions that can claim national status.

Themba Wakashe, chief director responsible for museums in the department, says that the review, which has already started, will not be confined to national museums, and may be completed in time for its conclu-

\section{IMAGE \\ UNAVAILABLE \\ FOR COPYRIGHT REASONS}

Sign of the times? Drought in the US.

question of potential human influence on climate change. John Shlaes, executive director of the GCC, argues that, under IPCC rules, any extra editing should have been peer-reviewed.

Shlaes concludes that the new version is unbalanced, contains "substantial deletions and significant changes" to the scientific material, and over-emphasizes the role of human activities in climate change.

$\mathrm{He}$ has written to Bert Bolin, emeritus professor of meteorology at the University of Stockholm and chairman of the IPCC, asking him to justify the decision to authorize additional editing. Copies of the letter have been sent to senior policy-makers in both houses of Congress.

The GCC analysis claims, for example, that the concluding summary has been deleted from the final report, and that a paragraph towards the end of the chapter plays down the uncertainty of establishing and forecasting human-induced climate change.

sions to be incorporated into the final draft of the white paper. Museums stripped of their national status could fall under provincial or local authorities - or possibly a combination of both - he adds.

The paper also proposes that a National Heritage Council be established. It would be responsible for allocating all funding that is currently distributed by the department. This would include distributing "operational" (salary and maintenance) funds between the various national collections, and "programme" funds, for which all museums can bid, irrespective of their status.

The department will meet leading officials of the Association of Directors of National Collections (ADNC) this week to discuss how to restructure the museums, in the hope that they may be able to formulate proposals to be included in the final version of the white paper. But it is not clear how museums that do not at present enjoy national status are to be involved in this process, if at all. Nor have provincial or municipal museums been included in a survey on rationalization.
"These revisions raise very serious questions about whether the IPCC has compromised, or even lost, its scientific credibility," says Shlaes. "The changes are not just about grammar and punctuation. They go deeper and we want to know why they were made."

But Santer defends the changes, which, he says, "can all be scientifically justified" and which were made in response to "the deluge of comments" he had received both from governments and from other scientists after the final draft had been circulated.

The concluding summary was removed for reasons of consistency, says Santer, as all other chapters in the report contain just one executive summary. References to uncertainties in climate modelling were not removed, he adds. "The executive summary and four and a half pages of Chapter eight are specifically devoted to the discussion of uncertainties in estimates of natural climate variability and the expected 'signal' due to human activities."

Santer describes as a "supreme irony" of the criticism the fact that he "fought very hard during drafting sessions to include sections on signal and noise uncertainties". $\mathrm{He}$ points out that many of his co-authors advocated removing these sections, on the grounds that the issues were partially covered in other chapters.

Sir John Houghton, co-chair of the IPCC's science working group, says the GCC's allegations are "scurrilous" and "have absolutely no basis in fact". The IPCC's rules of procedure, he contends, allow authors to make late modifications to the text.

The rules, he adds, state that documents are not "to be approved in detail" by working groups. This is designed to allow the modification of text that does not meet the criteria that an IPCC report must be "comprehensive, objective and balanced". Leaving the chapter unmodified would have breached IPCC procedures, says Houghton.

Houghton points out that many of the revisions were prompted by what he describes as "political interference" from the GCC. "They were openly lobbying Kuwait and Saudi Arabia in Madrid to try and weaken the science [in the report]. This was resisted by the IPCC, and we have now ended up with a document that is scientifically much better."

Santer says he is angry that the GCC "is making a big stink of the whole affair", especially because the report's key phrase "taken together, these results point towards a human influence on global climate" - was approved by all 100 participating governments and is contained in both the draft and the published IPCC report.

Santer adds: "I am really troubled by what is going on. This appears to be a skilful campaign to discredit the IPCC, me and my reputation as a scientist." Ehsan Masood 